\title{
MANAGING INSPECTIONS AND REPRESENTING SAFETY AT INDUSTRIAL PARKS
}

\section{ZARZACDZANIE KONTROLAMI I PREZENTOWANIE BEZPIECZEŃSTWA W PARKACH PRZEMYSLOWYCH}

\author{
Paolo Bragatto ${ }^{1}$, Maria Paola Bogliolo ${ }^{1}$, Paolo Pittiglio ${ }^{1}$ \\ ${ }^{1}$ ISPESL - National Institute for Occupational Safety and Prevention \\ Via Fontana Candida, 100040 Monteporzio Catone (Rome) Italy \\ E-mails: paoloangelo.bragatto@ispesl.it,mariapaola.bogliolo@ispesl.it, \\ paolo.pittiglio@ispesl.it
}

\begin{abstract}
At industrial sites, there are often problems of misperceptions of the risks by the local community and it is essential to make visible both hazards and safety activities to all stakeholders (employees, citizens, authorities). A software prototype has been developed in order to demonstrate the feasibility of a system for the presentation of safety activities within an industrial park. By means of a browser all safety activities are visible for the user. Both the activities undertaken by employers and those performed by the regulatory bodies may be monitored. At any time, the actual safety level may be demonstrated to any stakeholder. A correct perception of risks will be supported by this commitment to transparency.
\end{abstract}

Keywords: Inspections, Industrial Parks, Spatial Information System, Risk Perception

Streszczenie: $W$ zakładach przemystowych wystepuje często problem fatszywego postrzegania zagrożeń przez lokalne społeczności. Unaocznienie zarówno zagrożeń, ryzyka jak $i$ działań $w$ zakresie bezpieczeństwa, wszystkim zainteresowanym (pracodawcom, obywatelom $i$ władzom), jest sprawa zasadnicza. Opracowano prototyp oprogramowania $w$ celu zademonstrowania wykonalności systemu do prezentacji działań na rzecz bezpieczeństwa w parku przemystowym. Za pomoca wyszukiwarki użytkownik może podgladać wszystkie działania w tym zakresie. Monitorować można zarówno działania podejmowane przez pracodawców jak $i$ przez organa administracyjne. W każdej chwili każdemu udziałowcowi można przedstawić aktualny poziom bezpieczeństwa. To dziatanie na rzecz przejrzystości przyczyni się do prawidlowego postrzegania zagrożeń i ryzyka.

Stowa kluczowe: kontrole, parki przemystowe, system informacji przestrzennej, postrzeganie ryzyka 


\section{Introduction}

At industrial parks, inspections of mechanical and functional integrity are essential to prevent accidents. For this purpose, it is important to integrate all control activities (both mandatory and voluntary) in a management system, so that all controls can be used to obtain a sort of safety monitoring. As discussed by Bragatto et al. (2009), at any individual facility, all activities have always to be demonstrable to the regulators in the framework of major accident legislation. This idea may be transferred to industrial parks, which host many establishments in a fenced area. These structures are typical of chemical industry, where it is essential to share materials, utilities and structures.

At industrial parks synergies are aimed to increase efficiency and profitability but they may improve also safety activities, including inspection management. At these areas, there is often a problem of misperceptions of the risks by the local community and it is essential to make visible all safety activities to various stakeholders (employees, citizens, institutions of control). This commitment to transparency benefits the "virtuous" companies. Inspections are essential in industrial safety activities. If they are adequately planned, performed and managed, they contribute to reduce dramatically accident likelihood. If the information about inspection were available on a spatial basis, actual safety level could be demonstrated in an impressive way.

The paper present a software prototype, where the feasibility of this idea is demonstrated. In the next chapter the literature about inspection and spatial information systems is briefly reviewed; in the third chapter, objectives of the prototype are outlined. The fourth chapter is about the methods used to develop the software; the fifth one is about its features. The potential uses of the software are discussed in the sixth chapter. Different type of users (duty holders, inspection bodies, authorities) are discriminated. A case study is presented in the seventh chapter. Results are discussed in the last chapter.

\section{Spatial information for managing industrial risk}

Spatial information may be very useful in management of industrial risk. In assessing and managing major accident risk at geographic domains, use of Geographic Information Systems (GIS) is spreading, sometimes in conjunction with risk models. This approach takes advantage of the possibility to manage different types of information about land and the environment, to account for the presence of several hazardous (Seveso) 
establishments in an area, and to make use of available spatial analysis tools. One of the benefits coming from a GIS approach to land risk management is a direct link to land use planning, that has to account for industrial risk by law and is usually GIS supported. The question is discussed in many papers, e.g. Contini et al. (2000) and Spadoni et al. (2003).

At larger scales, GIS tools are widely used to manage infrastructures, particularly at oil \& gas companies to perform risk analysis, emergency response, inspection and maintenance, integrity management tasks on pipeline networks (Palmer, 2004). Asset management and maintenance tasks on infrastructure networks, usually performed by means of dedicated software (Computerized Maintenance Management Systems, CMMS) have been recently integrated by GIS, allowing the user to access any object either from maps or from database (Schmitz, 2002; McKibben and Davis, 2002).

Zooming to the plant domain, sophisticated software tools implementing a "geographic" approach to information management (full GIS approach or spatial maps associated with information databases) have been developed at big industrial companies or by third part commercial companies having plant managers as customers. Usually, these packages are multipart, being planned to carry out virtually any managing task concerning the plant (facility management, hazard studies managing licensing requirements and orders, safety management, risk based inspections etc.). One example is the COMPLIS (Complete Plant Information System) developed by ViaSecure (Deutschland $\mathrm{GmbH}^{\circledR}, 2010$ ). Other examples are the set of Digital Plant solutions by Bentley (2010) and the ABB (2010) Aspect Objects (in this latter product, objects location is accessed through logical organization and displayed onto process schemes rather than onto plant maps).

Recently, a system was developed in Italy (Costantini et al., 2009) aimed to support fire emergency at industrial sites undergoing Seveso regulation in Tuscany (central Italy). It is based on an information system based on alphanumerical and cartographic data concerning the establishment safety plans. The forms give access to maps (CAD plans) showing the location of hazardous areas and support-to-emergency features.

The idea of improving inspection management by means of spatial information is, however, quite new. There are just a couple of papers. Straub et al. (2009) have demonstrated how the planning of inspection activities for large concrete structures may be improved by representing spatial and temporal variability. Ruiz and Fernandez (2009) have presented a Decision System based on the Geographical Information System (GIS) for the 
inspection management in building industry. The application of this approach to the process industry is definitely new in the literature.

\section{Objectives}

The software was planned with the aim of integrating control and safety activities in a management system, to obtain a sort of safety monitoring, and using strategies to make its use immediate and concise. These features were obtained by means of a spatial access to information, based on location maps of the units and devices of interest, and using graphic symbols to convey main information.

Needs of three potential users were considered in planning the software:

Safety Manager

At the establishment, the Safety Manager must arrange the schedule for inspections (both voluntary and mandatory). He has also to demonstrate the effectiveness of safety management, both for the voluntary certification system (e.g. BS 18001) and for the fulfillment of the legislation on control of major accident hazard (e.g. Seveso).

Control Agency

The Control Agency has to act effectively, programming on-site inspections optimizing both logistics and costs. At the plant, operators should have a synthetic way to direct the choice of spot checks on critical units.

Other Stakeholders

An immediate and intuitive presentation of what is continuously done for safety inside hazardous plants can stimulate in local authorities, land planners, and non-governmental organizations (e.g. representing inhabitants community) a better balanced awareness of local industrial risk.

\section{Methods}

The software developed is a kind of browser that allows the user to manage, query and present all the control activities that are actually done in the departments of the factory, in order to ensure the safety of operation. Both the activities undertaken by employers and those performed by the control entities may be monitored.

\subsection{Risk and safety representation}

When the area of concern is contained inside the boundary of the establishment, standard risk representations, which are commonly used at 
cartographic scale, do not make sense. While outside the plant, sources and targets are clearly separated, within the establishment they are inseparable indeed: outside, people are considered potential victims; inside, workers have an active role in the chain of events leading to different scenarios. Equipment too, depending on inspections and maintenance, can rise or prevent accidents. Consequently, a clear presentation of activities for safety is important when the plant domain is considered.

In order to represent safety, the hierarchical division in plant areas, logical units, items of equipment, components and devices has been considered.

Some innovative representations, which have been developed "ad hoc", are listed below.

Risk Ranking

The relative importance of units was represented using the well known Dow Fire \& Explosion Index. It was graphically symbolized on the CAD maps of the establishment by means of a vanishing red circle with radius proportional to the Index. It appears just when the cursor passes over a unit or a component.

Synopsis

For the components present in the units, a synopsis of the program of inspections and progress is displayed. A similar representation is possible on the devices associated with each item of equipment. In this way the user can fall from a level of overall integrity control to a detailed audit on the functionality of each individual device.

Semaphore

A semaphore symbol is used to represent the responsiveness of the control activities performed. Of course, the green means controls performed according to the schedule are shown in green; those close to expiration are in yellow; expired controls are in red.

\subsection{Integration with GIS}

This prototype was successfully integrated into a Geographic Information System (GIS) which manages data on land use and vulnerability factors, for land planning and emergencies managing purposes. The GIS is aimed at providing a general reference, delivered via web, to help building, evaluating and transferring geographic information needed to assess risk in areas where hazardous industrial plants are located.

Contents and organization of the GIS were defined in a data model, studied to be applicable to every Italian area having hazardous plants. The model describes the GIS in the following components: cartographic reference 
system; maximum and minimum display scales; domain range; contents; structure of the geographic and alpha-numeric databases; implementation of some tools. Contents were defined in terms of type information, thematic layers materializing that information and data sources. Public sources were chosen whenever possible.

Since the main focus of the GIS is on the area surrounding the establishment, and the main concern is safety outside its boundary, plants are mainly viewed as hazard sources. Information useful to define the hazard associated with the plant (top events, scenarios, damage distances and damage areas) is georeferenced, and databases containing alphanumeric information about the plants are accessible geographically. At the maximum display scale (about 1:1000), georeferenced CAD layouts of the plant are shown.

The link with the software for inspection management is provided trough the database carrying general information about the hazardous plants. This latter is directly accessible from cartography with a mouse click on the polygon representing the plant of interest. In the main form displayed to the user, a command button launches the main page (general CAD layout) of the software for the queried establishment (see fig. 3).

As a result, starting from a GIS display of the region of interest, the user can select an industrial plant graphically or as the outcome of logical and spatial constraints imposed on different information layers. Then, he/she can go on zooming on the plant, to consult (and possibly managing) information concerning single units and devices inside it.

\section{Prototype characteristics}

The software is basically a database coupled with a graphical visualizer. The first one holds information about equipment and related activities within the park, the second one allows the user to access information through the plant layout. Adobe Flash has been used for the graphical interface and MySql for the database. The database on the central server may be accessed by concurrent users. In the present implementation, the ISPESL intranet has been exploited. It connects the research center, the head and administrative offices and the local branch, which is competent for the inspections at the industrial parks.

The software acts as a browser, with a tree-type navigation, allowing both graphical and textual access to information at different levels, and the possibility of returning to main pages and of commuting between graphical and textual modes at every level. 
Graphical information about location of the various features is provided by CAD layouts of the establishment (or industrial park) that are available in "cascade", with increasing detail. Access to information is obtained through sensitive areas of the map. These areas activate by moving the cursor on them showing concise and detailed information in form of labels, graphic symbols, data sheets and detailed maps that are sensitive in turn.

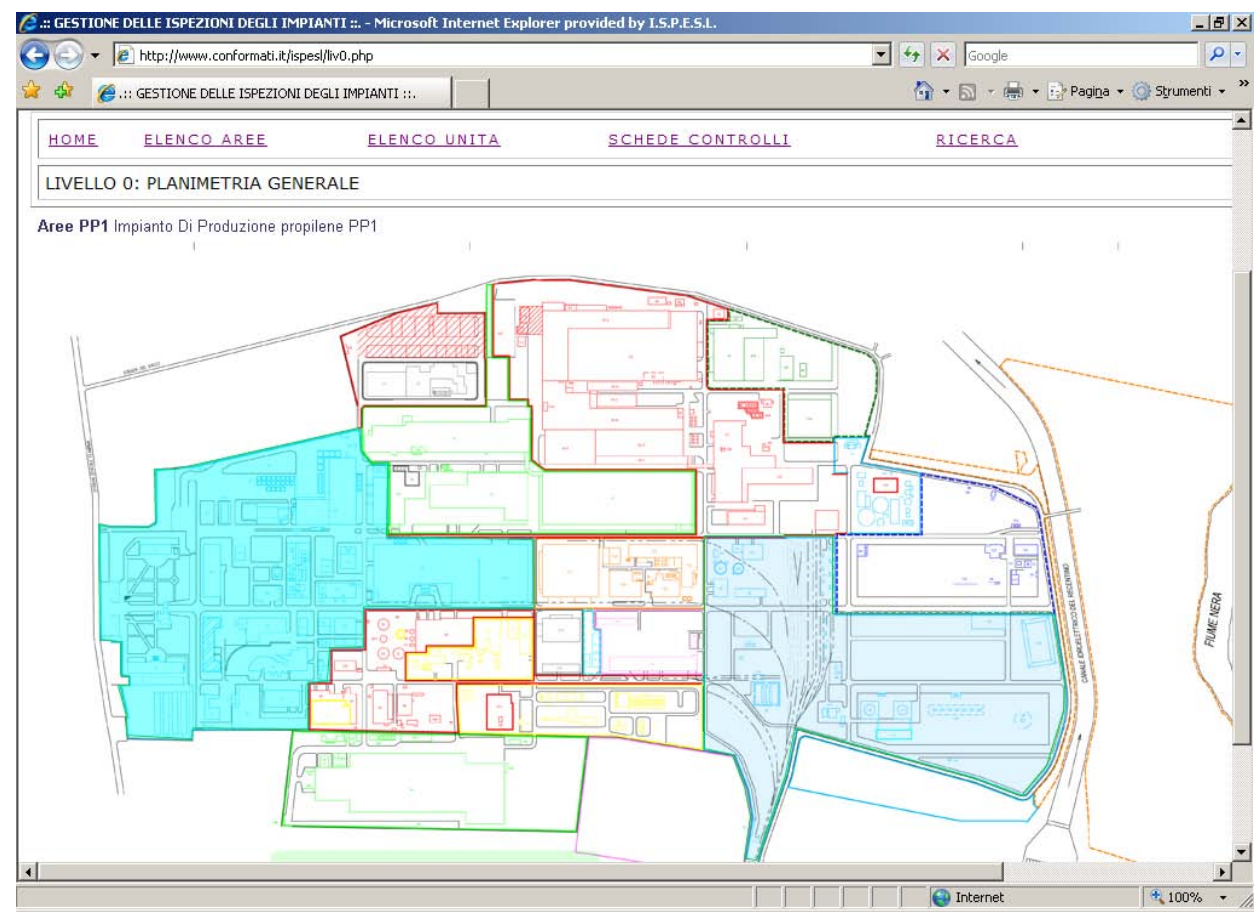

Fig. 1 The main page of the software is shown for the industrial park used as a case study. The active area on the left is described by an identification label on the upper-left part of the screen.

Navigation starts from the general establishment (or industrial park) layout, giving access to more detailed layouts. From the layout of each unit, showing concise indication of risk ranking, an information sheet lists all components and their characteristics; from them, it is possible to list the other features, with increasing detail (e.g. equipment, accessories), according to a logical tree structure. Each item has an individual data sheet. At every level, graphic screenshots, descriptions, data and information may be selected and accessed. Textual information and images may be combined, with direct import from different file formats. Textual sheets give 
the option of new entries and changes, that are immediately recorded, thus keeping the system up to date.

Each feature gives access to the control sheet containing all information about safety activities performed on it, including the timetable and the record of operations performed. The updated situation of controls is also symbolized with the semaphore feature (chapter 4).

The layout shown in Figure 1 is a screenshot of the main page of the software prototype populated with data from a case study (see Chapter 7). Two areas on it (production and storage) are sensitive: the cursor on them activates the area identification label (upper left side of the screenshot: "Area PP1")

A click on the selected area opens the corresponding detailed map, where the various units, with their components, are shown (Fig. 2). Each of them is sensitive, and the cursor activates a description label and a graphic symbol. The label shows the unit name and code; the value of the Dow Fire \& Explosion Index and the relative exposure radius; the value of the (intrinsic) risk index $G$, as defined by the Italian regulation, with the corresponding level on the reference scale. The graphic symbol is a red circle which size is proportional to the Dow Index, representing a concise risk ranking.

A click of the cursor on the unit opens the corresponding information sheet. The sheet is organized in fields that can contain:

- data, pictures, tables, text describing the unit, with the option to make entries and changes;

- list and description of components, including distinctive parameters, identification data, description of control devices;

- the control sheet containing information about inspection activity (date, operator's name, control classification, execution state), with the option to make entries and changes. The semaphore symbol summarizes the updated state of each control.

At each browsing level, links to previous/main pages are available (main layout, list of plant areas, menu, etc.) as well as to the control sheet for a certain unit or for the establishment as a whole. 


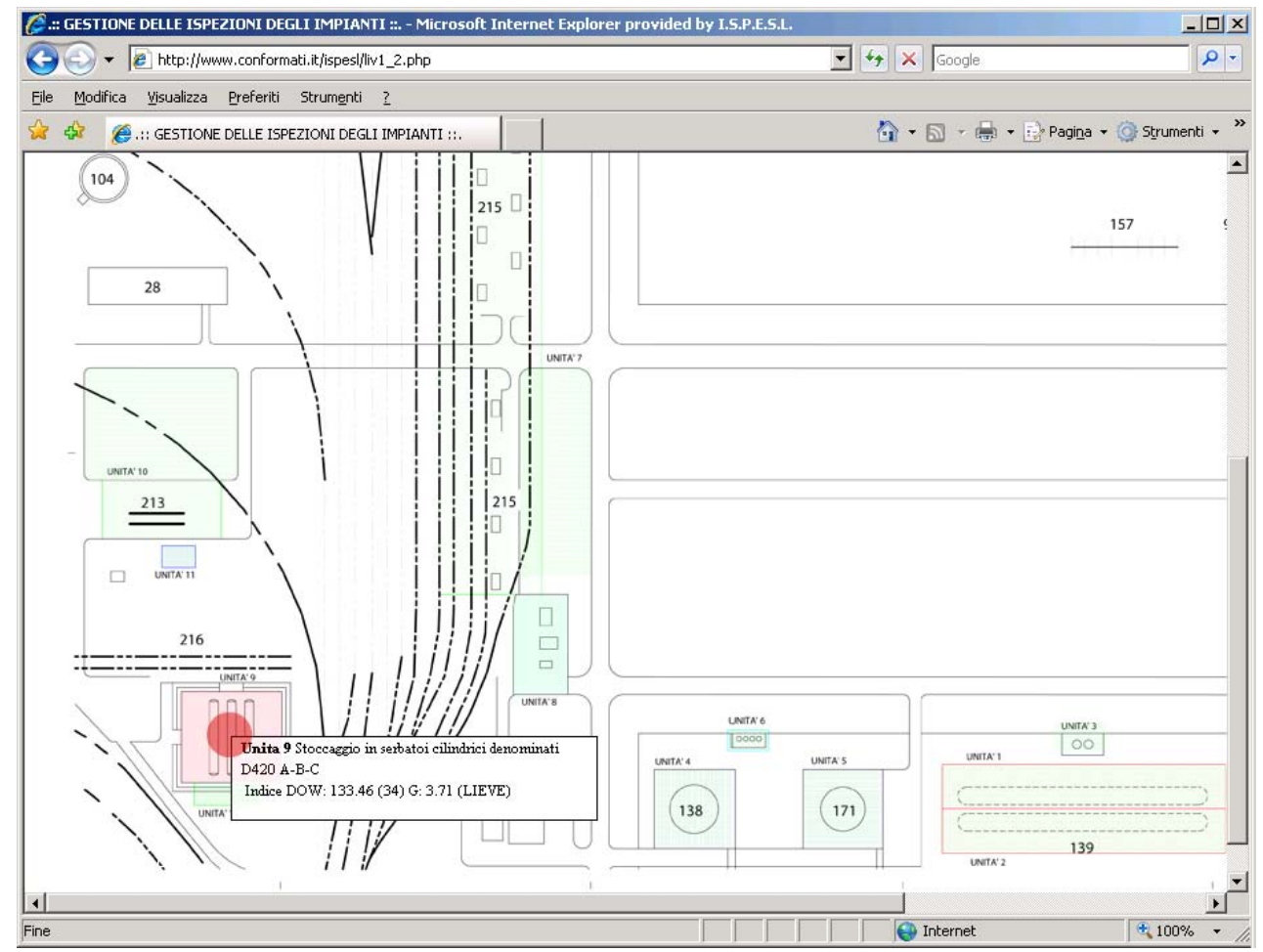

Fig. 2 The layout of the PP1 area of Fig. 1 is shown. All units located in the area are sensitive to the cursor. Unit 9 shows the description label and graphics activated by the cursor.

\section{Case study}

The prototype was tested using real data concerning two major hazard facilities, namely a petrochemical plant and a large liquefied petroleum gas depot, included in an industrial park located in the outskirts of the city of Terni (central Italy). The software was populated with data provided by the regulatory activities of ISPESL, which includes the certification and periodical examination for pressure equipment and the audit of the safety management system for major accident hazard establishments.

The software was then integrated into a Geographic Information System built for the area where the industrial park is located. The GIS, managed by the ESRI ${ }^{\circledR}$-ARGIS software package, contains basic information needed to estimate and report the safety level of the land area surrounding the industrial park. The general cartographic reference is provided by a satellite high resolution multispectral image (IKONOS) that was pre-processed to increase the detail and accurately georeferenced. Most information 
concerning vulnerability was retrieved from the Municipality and District Land Plans encompassing the area of interest. Hazard information about the plant was extracted from the safety plant documents.

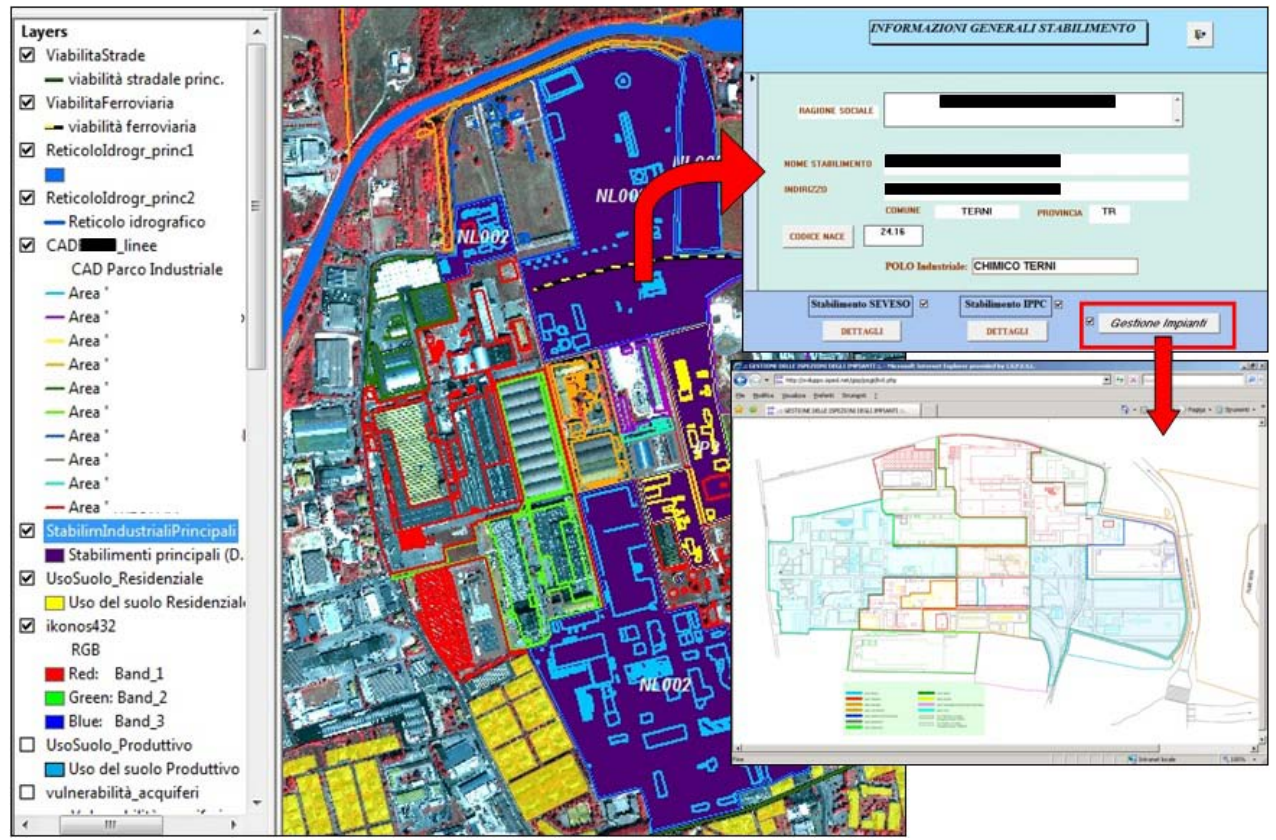

Fig. 3 An example of GIS information. The names of the establishments have been blanked for privacy reason.

In Figure 3 an example of information accessible in the GIS is shown. In the map of the industrial park used as a case study, some of the available thematic layers are displayed (e.g. georeferenced CAD map). A click on the map activates the DB form containing general information concerning the establishment. A command button launches the software for inspection management, at the main page of the queried plant.

\section{Result discussion}

The software has been successfully tested by control bodies for the proposed objectives. It has been demonstrated very useful for a less emotional perception of risk at industrial areas, as "Risk" and "Safety" are presented in the same glance. 


\subsection{Potential users}

Through this software, the establishment layouts can be used as a graphical interface to access the database of inspections. It can be useful both for the plant manager and for entities in charge of inspections.

Plant manager

At the establishment, the safety manager could use the software to schedule both the voluntary and, when required by law (e.g. pressure vessels), the mandatory inspections.

Inspection activity can be optimized according to equipment location. For example, when a unit has been stopped, it could be appropriate to undergo controls of all equipment with expiration date within one or two years, in order to avoid successive disturbance to plant activity.

In case of adoption of Risk Based Inspection policy, the software can be valuable to obtain an overall snapshot of ongoing safety activities and to monitor the actual implementation of the inspection schedule developed through the RBI methodology.

The contextual display of units/equipment/inspections can also help to quickly direct private and public inspectors within the plant, avoiding wasting time.

\section{Control Agencies}

Regulators use preventive maintenance schemes. An essential component of most preventive schemes is the determination of appropriate service intervals for every plant item. The system can be useful since it raises alerts when it is time for inspection, thus preventing delay.

In case of industrial parks, controls may be grouped by type and location, in order to maximize the activities in a single visit and reducing travel costs.

For inspections conforming to art.18 of the Seveso Directive, adequacy of controls on equipments can be verified according to the hazard level of the logical unit.

Contextual representation of layout, hazards and equipments may also be used as a guide to implement spot checks on critical units.

\section{Other Stakeholders}

Graphical symbology included in the software (e.g. semaphore) provides an immediate and concise way to summarize safety activities for local authorities, land planners, NGOs, interested in connecting risk outside the 
plant (as shown in GIS maps) with safety ensured by inspections and controls inside it.

\subsection{Connection with the GIS}

The connection set between the plant domain (Inspection software) and the regional domain (GIS) results in a comprehensive system that allows a continuous flux of information concerning safety, from the regional level, to the single plant unit. A way is hence provided, to highlight the relation between intrinsic safety of the units and land safety for people and environment: the reliability of plant components, secured by inspections, becomes a key element in the probabilistic risk assessment, as required for quantitative risk analysis (QRA) and land use planning (LUP).

As a practical advantage provided by interfacing the two systems, planning criteria of safety activities inside the plant can be combined with logistic concerns at the local area scale. As an example, public authorities in charge of inspections can optimize their activity both inside the plant, referring to the Inspection software, and at the regional scale, driven by the GIS, based on the location of the plants that have to undergo inspections.

\section{Acknowledgements}

The research was carried out in the framework of the project "Valutazione dello stato dell'ambiente dell'area denominata Conca Ternana" funded by the Italian Ministry for Health (Call 2004).

\section{References}

1. ABB: Aspect Objects. URL: http://www.abb.com/cawp/seitp161/c125692200 220ad3c125689e0052f560.aspx. Last visited on 9 March 2010.

2. Bentley: Digital Plant Solutions. URL: http://www.bentley.com/enAU/Products/Bentley+Digital+Plant/Quicklink.htm. Last visited on 9 March 2010.

3. Bragatto P.A., Pittiglio P., Ansaldi S.: The management of mechanical integrity inspections at small-sized Seveso facilities. Reliability Engineering and System Safety, v. 94, p. 412-417, 2009.

4. Contini S., Bellezza F., Christou M., Kirchsteiger C.: The use of geographic information systems in major accident risk assessment and 
management. Journal of Hazardous Materials, v. 78, no.1-3, p. 223-245, 2000.

5. Costantini R., Angeli L., Costanza L., Falsetti S., Ferrari R., Dilani R., Notaro F.: SISA: sistema Informativo di Supporto agli Interventi Antincendio nell'ambito delle imprese. Atti della 13a Conferenza Nazionale ASITA (Bari, 1-4 Dicembre 2009), p. 777-782.

6. McKibben J. \& Davis D.: Integration of GIS with Computerized Maintenance Management Systems (CMMS) and Asset Management Systems.

URL: http://proceedings.esri.com/library/userconf/proc02/pap0554/p0554.htm. 2002. Last visited: 9 March, 2010.

7. Palmer J.: GIS plays critical role in data management and pipeline integrity. Pipeline and Gas Journal, v. 231, no. 2, p. 33-35, 2004.

8. Ruiz M.C., Fernández I.: Environmental assessment in construction using a Spatial Decision Support System Automation in Construction, v. 18, no. 8, p. 1135-1143, 2009.

9. Schmitz B.: Integration of computerized maintenance and GIS. URL: http://

www.gisdevelopment.net/proceedings/gita/2002/sysint/gita2002077pf.ht m. 2002. Last visited on 9 March 2010.

10. Spadoni G., Contini S., Uguccioni G.: The new version of ARIPAR and the benefits given in assessing and managing major risks in industrialised areas. Process Safety and Environmental Protection, v. 81 no. 1, p. 19-30, 2003.

11. Straub D., Malioka V., Faber M.H.: A framework for the asset integrity management of large deteriorating concrete structures Structure and Infrastructure Engineering, v. 5, no. 3, p. 199-213, 2009.

12. ViaSecure Deutschland $\mathrm{GmbH}^{\circledR}$ : COMPLIS. URL: http://www.viasecure.eu /index.php?option $=$ com_content\&view $=$ category\&layout $=$ blog\&id $=38$ \&Itemid=88\&lang=en. Last visited on 9 March 2010. 

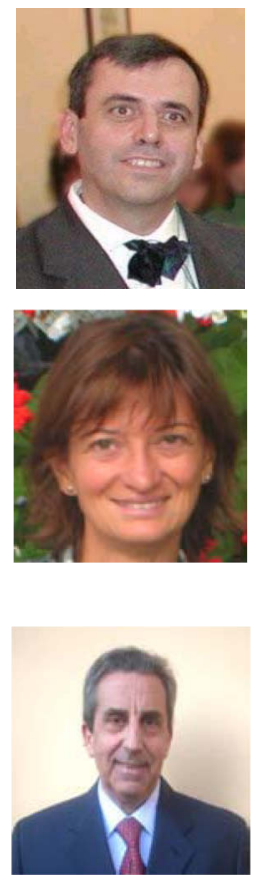

Paolo Bragatto. Born 1955. MSc in Physics. Scientist at ISPESL Research Center for some fifteen years. Previously engineer of a large industrial group. Research fields: risk analysis, safety management systems, risk based inspections. Inspector at Seveso establishments. Author of some thirty papers published in international journals and books and over fifty papers in Italian.

Maria Paola Bogliolo Born in 1964. Msc in Geology and specialized in Remote Sensing. Previously at the National Institute for Geophysics and Volcanology, she has worked as a researcher at ISPESL since 1998. Research activity: application of Remote Sensing and GIS in study and management of industrial pollution and risks. Member of the ISPESL group for the examination of remediation working plans at the main Italian contaminated sites.

Paolo Pittiglio. Born 1949. MSc in Nuclear Eng. Research Manager. He has served ISPESL for almost thirty years. Previously at National Association for Combustion Control. Research fields: Major Accident Hazard, LNG and hydrogen safety. Author of technical and scientific papers. Inspector for Major Accident Hazard. Member of Environmental Impact Assessor for the Ministry of Health. 